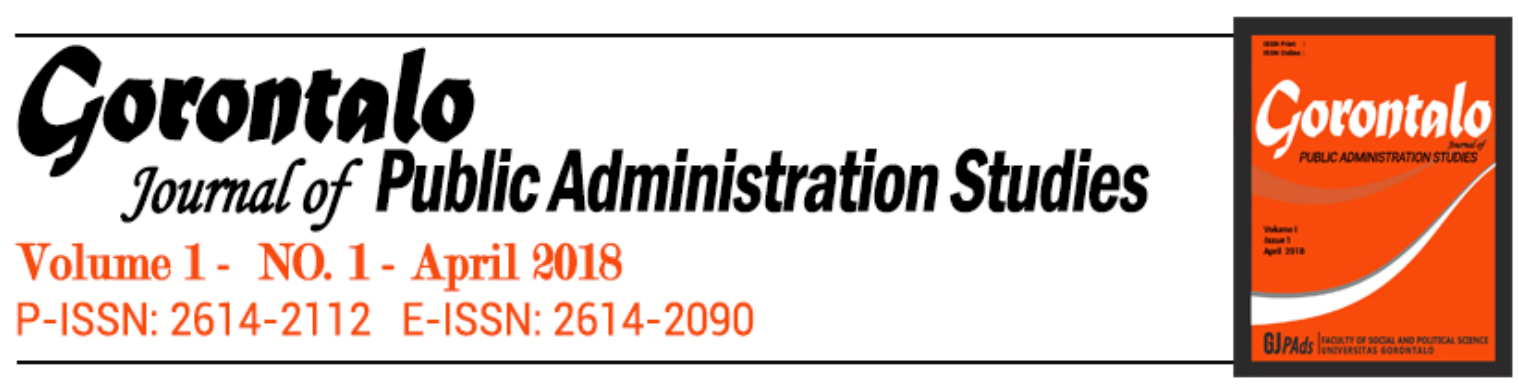

\title{
Peranan Aparat Desa dalam Pelaksanaan Administrasi Pemerintahan Desa di Desa Karyamukti Kecamatan Mootilango Kabupaten Gorontalo
}

\author{
Muh. Fachri Arsjad \\ Program Studi Ilmu Administrasi Publik, Universitas Gorontalo \\ Fachri_arsjad@gmail.com
}

\begin{abstract}
The main problem in the research is the role of village officials in the implementation of village administration Village Karyamukti District Mootilango Gorontalo District. The purpose of this study to determine the role of village officials in the implementation of administrative tasks of village government. The research method used is quantitative method, and research type is descriptive. Techniques of collecting data through interviews, observation and documentation. Informants in this study were the village head, three heads of affairs, and the village secretary. The results show that: First, the role of village officials in the implementation of administrative duties in the Village Karyamukti Mootilango Gorontalo Gorontalo district is still less than the maximum. The assessment is because of the three heads of affairs, both government, development, and general recognize that its role has not been maximal in carrying out its duties and functions effectively. Secondly, the factors that influence the effort of improving the village apparatus in the implementation of administrative duties in Karyamukti village are the discipline of work, education and training, facilities and infrastructure and the level of welfare of village government apparatus.
\end{abstract}

Keywords: government administration; village aparatur; Gorontalo Regency.

\begin{abstract}
ABSTRAK
Masalah utama dalam penelitian ini adalah peran aparat desa dalam pelaksanaan pemerintahan desa Desa Karyamukti Kecamatan Mootilango Kabupaten Gorontalo. Tujuan penelitian ini untuk mengetahui peran aparat desa dalam pelaksanaan tugas administrasi pemerintahan desa. Metode penelitian yang digunakan adalah metode kuantitatif, dan jenis penelitiannya adalah deskriptif. Teknik pengumpulan data melalui wawancara, observasi dan dokumentasi. Informan dalam penelitian ini adalah kepala desa, tiga kepala urusan, dan sekretaris desa. Hasil penelitian menunjukkan bahwa: Pertama, peran aparat desa dalam pelaksanaan tugas administrasi di Desa Karyamukti Mootilango Kabupaten Gorontalo Gorontalo masih kurang maksimal. Penilaian ini karena tiga kepala urusan, baik pemerintah, pembangunan, dan umum mengakui bahwa perannya belum maksimal dalam menjalankan tugas dan fungsinya secara efektif. Kedua, faktor-faktor yang mempengaruhi upaya peningkatan aparat desa dalam pelaksanaan tugas administrasi di desa Karyamukti adalah disiplin kerja, pendidikan dan pelatihan, sarana dan prasarana dan tingkat kesejahteraan aparatur pemerintah desa.
\end{abstract}

Kata Kunci: administrasi pemerintahan; aparatur desa; Kabupaten Gorontalo. 


\section{PENDAHULUAN}

Desa merupakan system penyelengaraan pemerintahan paling dibawah dalam pembangunan, mengigat pemerintah desa merupakan basis pemerintahan terendah dalam struktur pemerintahan Indonesia yang sangat menetukan bagi berhasilnya ikhtiar dalam pembangunan nasional yang menyeluruh. Kompleksnya aspek-aspek atau bidang yang hendak dibangun ditingkat pemerintah desa adalah peningkatan kemampuan aparat pemerintah desa dalam pelaksanaan tugas-tugas adminitrasi pemerintah, disamping memperkuat partisipasi masyarakat dan kelembagaannya serta aspek-aspek lainya.

Pemerintah desa beserta aparatnya bertugas sebagai administrator penyelenggara pemerintahan, pembangunan dan kemasyarakatan. Oleh sebab itu diperlukan aparat desa yang benar-benar mampu dan dapat bekerjasama dalam pelaksanaan tugas dan memiliki tanggung jawab. Keberadaan aparat desa yang juga diserahi tugas dibidang administrasi, menduduki posisi yang sagat penting karena sebagai organ pemerintah yang paling bawah mengetahui segala kondisi dan permaslahan yang ada diwilayahnaya. Informasi tersebut dikoordinasika pada pemerintah kecamatan karena dibutuhkan dalam pengambilan kebijaksanaan daerah maupun nasional untuk kebutuhan pembangunan secara menyeluruh. Dengan demikian kepala desa dalam pelaksanaan tugas dituntut untuk lebih optimal guna mempelancar pelaksanaan tugas pemerintah.

Berangkat dari pemikiran tersebut jika dikaitkan dengan realitas pada aparat Desa Karyamukti Kecamatan Mootilanggo Kabupaten Gorontalo menujukan bahwa kemampuan kepala desa karyamukti dalam pelasanaan tugas terutama dalam menyiapkan bahan dan informasi yang di butuhkan untuk kepentingan perencanaan pembangunan, hasilnya masih minim atau belum terlaksana secara optimal. Hal ini terbukti dari pelaksanaan tugastugas administrasi yang tidak terlaksna dengan baik dan konsisten sesuai ketentuan, baik administrasi umum, administrasi penduduk, maupun administrasi keuangan.

Administrasi umum adalah semua pekerja, kegiatan dan tata cara tulis menulis dalam lingkungan organsasi seacara teratur da terarah bersifat non oprasional dan dilaksanakan oleh seluruh bagian organisasi untuk mencapai tujuan. Administarasi kependudukan adalah rangkaian kegiatan penataan dan penertiban dalam penertiban domkumen dan data kependudukan melaluai pendaftaran penduduk, pencatatan sipil, penggelolaan informasi penduduk serta pendayagunaan hasilnya untuk pelayanan publik dan pembangunan sektor lain. Sementara Admnistrai keuangan dalam arti luas adalah penggurus dan pertanggung jawaban baik pemerintah pusat maupun daerah. Informasi desa karyamukti belum tersedia dengan baik sesuai dengan proses pengadministrasian pemerintah desa.

Belum tersedianya informasi dari administrasi desa secara baik karena pengaruh faktor sumber daya aparat desa yang belum optimal. Dalam penyelenggaraan pemerintahan desa yang terpenting adalah bagaimana pemerintah desa mampu meningkatkan kesejahteraan rakyatnya, mampu memberikan pelanyanan kepada masyarakat desa, dan mampu meningkatkan daya saing desanya. Hal tersebut hanya mungkin terwujud apabila urusan yang menjadi kewenangan desa dapat terlaksanakan dengan 
baik,. Administrasi pemerintahan desa terdapat berbagai permasalahan, baik secara langsung maupun tidak langsung menghambat pelaksanaan urusanurusan pemerintahan desa.

Administrasi Desa adalah keseluruhan proses kegiatan penyelenggaraan pemerintahan dan pembangunan dengan memanfaatkan kemampuan aparat desa serta segala sumber yang ada untuk mencapai tujuan yang ditetapkan yaitu terwujudnya peningkatan partisipasi dalam pemerintah dan pembangunan serta penyelenggaraan admistrasi yang makin meluas dan efektif. Pengelolaan administrasi pada organisasi pemerintahan desa merupakan suatu tuntutan yang sangat diperlukan. Karena dengan terbentuknya administrasi yang baik dibidang pemerintahan, maka proses pembangunan dan kegiatan pemerintahan pada tingkatan desa akan berhasil dengan baik apabila didukung oleh suatu sistim administrasi yang tertib dan teratur.

Kapasitas yang masih rendah merupakan bagian dari permaslahan administrasi dan aparat desa karyamukti. Diantaranya masih belum optimalnya aspek kelembangaan, sumber daya manusia, maupun manajemen pemerintahan desa. Pada tahun 2008 Pusat Kajian Kinerja Otonomi Daerah, telah melaksanakan kajian peningkatan kapasitas pemerintahan desa, kajian ini telah menghasilkan cetak biru (blueprint) yang memuat strategi-startegi penyelesaian masalah (problem solving) penyelenggaraan pemerintahan desa dan menyusun modul-modul peningkatan kapasitas pemerintah desa. Namun usaha tersebut masih belum mampu menyelesaikan berbagai permasalahan dalam menjalankan perana aparat desa dalam melaksanakan tugas adaministratif pemerintahan di desa karyamukti. Oleh karena itu, perlu dilakukan pengkajian mendalam dalam menyelesaikan permasalah pemerintah di desa karya mukti.

\section{KAJIAN TEORI}

\subsection{Konsep Kemampuan Aparat Desa}

Konsep kemampuan dalam suatu organisasi pemerintahan desa memiliki suatu daya kesanggupan, keterampilan, pengalaman terhadap pekerjaan dalam pengimplemntasian tugas-tugas dan fungsi masing-masing aparat desa. Kemampuan yang penulis maksudkan adalah kemampuan yang dilihat dari hasil kerjanya atau kemampuan kerjannya. Kemampuan kerja seseorang menurut Tjiptoherianto (1993:36) mengemukakan bahwa kemampuan kerja yang rendah adalah akibat dari rendahnya tingkat pendidikan dan latihan yang dimiliki serta rendahnya derajat kesehatan.

Dalam Undang-undang Nomor 6 tahun 2014 tentang desa yang telah disahkan pada 15 januari 2014 lalu terdapat beberapa perubahan. Perubahan tersebut menunjukkan tentang masa jabatan kepala desa menyebutkan bahwa masa jabatan kepala desa adalah 6 tahun dan dapat menjabat 3 kali masa jabatan secara berturut-turut. Selain itu, kemampuan aparat desa dapat dilihat dari tingkat pendidikan aparat, jenis latihan yang pernah diikuti dan pengalaman yang dimilikinya. Steers berpendapat bahwa pada kenyataanya anggota organisasi yang merupakan faktor yang mempunyai pengaruh yang paling penting dalam pencapaian tujuan organisasi disebabkan orang-orang itulah yang menggerakan roda organisasi. 
Pemerintah desa memiliki peran signifikan dalam pengelolaan proses sosial didalam masyarakat. Tugas utama yang harus diemban pemerintah desa adalah bagaimana menciptakan kehidupan demokratik, memberikan pelayanan sosial yang baik sehinga dapat membawa warganya pada kehidupan yang sejahtera, rasa tentram dan berkeadilan. Guna mewujudkan tugas tersebut, pemerintah desa dituntut untuk melalakukan perubahan, baik dari segi kepemimpinan, kinerja birokrasi yang berorientasi pada pelayanan yang berkualitas dan bermakna, sehinga kinerja pemerintah desa mengarah pada praktek good local governance, bukannya bad governance.

Peluang untuk menciptakan pemenrintah desa yang berorientasi pada good local governanace sebenanrnya dalam konteks transisi demokrasi seperti yang dialami oleh bangsa Indonesia sekarang terbuka cukup lebar. Hal ini didukung oleh kondisi sosial pasca otoritarianisme orde baru yang melahirkan liberalisasi politik yang memungkinkan seluruh elemen masyarakat desa bebas mengekspresikan gagasan-gagasan politiknya. Meskipun demikian, adanya perubahan sosial politik dalam masa transisi demokrasi ini tidak dengan serta merta dapat merubah dalam sekejap wacana dan kinerja pemerintahan desa kedalam visi demokratisasi dan good local governance, sekalipun stuktunya mengalami perubahan. Saat ini pemerintahan desa tidak lagi bercorak korporatis dan sentralistik pada kepemimpinan kepala desa, akan tetapi kultur dan tradisi yang memposisikan kepala desa sebagai orang kuat dan berpengaruh masih begitu melekat dan kuat. Realitas ini memang tidak dapat dilepaskan sebagai bagian dari proses konstruksi sosial yang begitu mendalam sehingga membuat daya kognitif warga desa seringkali terasa kesulitan dalam membuat terombosan-terombosan baru yang sejalan dengan semagat perubahan ketika berbenturan dengan kebijakan seorang kepala desa.

Kondisi ini sedikit banyak juga dipengaruhi pula oleh lemahnya human resources didesa yang populasinya relative kecil dan sangat terbatas. Oleh Sebab itu guna mendobrak kebekuan atau stagnasi sosial ini diperlukan terobosan dari kekuatan luar untuk bermitra atau saling bekerja sama dengan aktor-aktor dan lembaga-lembaga potensi desa dalam melakukan perubahan sosial menuju kearah situasi yang lebih baik dibandingkan dengan sebelumnya.

\subsection{Konsep Administrasi Pemerintahan Desa}

Sadu Wasistiono mengatakan bahwa, tanpa adanya pemerintahan desa yang kuat, desa dengan masyarakat hanya akan menjadi obyek permainan ekonomi maupun politik dari pihak-pihak luar desa yang reltif lebih kuat posisinya. Dalam peranan pemerintah desa sebagai sturktur perantara adalah sebagai penghubung antara masyarakat desa dengan pemerintah dan masyarakat di luar desa tetap dipertahankan, bahkan ditambah dengan peranan lainya yaitu sebagai agen pembaharuan. Desa atau dengan nama lainya yang sejenis menurut konstitusi memperoleh perhatian istimewa. Berbagai bentuk perubahan sosial yang terancam dengan nama pembangunan guna meningkatkaan harkat dan martabat masyarakat desa diperkenalkan dan dijalankan melalui pemerintah Desa. 
Secara etimologis administrasi berasal dari bahasa latin administrare, suatu kata kerja yang berarti melayani, membantu, menujang, atau memenuhi. Istilah ini berasal daru kata benda administration dan kata sifat administratifus. Administrasi juga dapat diartikan sebagai:

1. Suatu aktivitas yang terutama bersangkutan dengan cara untuk menyelenggarakan tujuan yang telah ditentukan semula,

2. Suatu proses laizim terdapat dalam segenap usaha bersama, baik usaha berskala besar maupun kecil-kecilan.

3. Suatu proses pengorganisasian dan bimbingaan orang-orang agar dapat melaksanakan suatu tujuan khusus,

4. Suatu proses penyelenggaraan dalam setiap usaha kerjasama sekolompok manusia untuk mencapai tujuan-tujuan tertentu,

Menurut peraturan mentri dalam negeri nomor 32 tahun 2006 menyatakan bahwa administrasi desa adalah keseluruhan proses kegiatan pencatatan data dan informasi mengenai penyelenggaraan pemerintah desa pada buku adminstrasi dewsa. Adapun jenis-jenis adaministrasi desa sebagai berikut:

\subsubsection{Administrasi Umum}

Administrasi Umum adalah kegiatan pencatatan data dan informasi mengenai kegiatan pemerintahan desa pada buku administrasi umum, terdiri dari Buku Data Peraturan Desa, Buku Data Keputusan Kepala Desa, Buku Data Inventaris Desa, Buku Data Aparat Pemerintah Desa, Buku Data Tanah Milik Desa/Tanah Kas Desa, Buku Data Tanah Di Desa, Buku Agenda, Bukun Ekspedisi

\subsubsection{Administrasi Penduduk}

Administrasi Penduduk adalah kegiatan pencatatan sata dan informasi mengenai penduduk dan mutasi penduduk pada buku administrasi penduduk terdiri dari: Buku Data Induk Penduduk Desa, Buku Data Mutasi Penduduk Desa, Buku Data Rekapitulasi Jumlah Penduduk Akhir Bulan, Buku Data Penduduk Sementara.

\subsubsection{Administrasi Keuangan}

Administrasi Keuangan adalah kegiatan pencatatan data dan informasi mengenai pengelolaan keuanagan desa pada buku administrasi keuangan terdiri dari: Buku Anggaran Penerimaan, Buku Anggaran Pengeluaran Rutin, Buku Anggaran Pengeluaran Pembangunan, Buku Kas Umum, Buku Kas Pembantu Penerimaan, Buku Kas Pembantu Pengeluaran Rutin, Buku Kas Pembantu Pengeluaran Pembngunan.

\subsubsection{Administrasi Pembangunan}

Administrasi Pembangunan adalah kegiatan pencatatan data dan informasi pembangunan yang akan, sedang, dan telah dilaksanakan pada buku administrasi pembangunan, terdiri dari : Buku Rencana Pembangunan, Buku Kegiatan Pembangunan, Buku Inventaris Proyek, Buku Kader-Kader Pembangunan/Pemberdayaan Masyarakat.

\subsubsection{Administrasi Badan Permusyawaratan Desa (BPD)}

Administrasi badan permusyawaratan desa (BPD) atau yang disebut dengan BPD adalah kegiatan pencatatan data dan informasi mengenai BPD, terdiri dari: Buku Data Anggota BPD, Buku Data Keputusan BPD, Buku Data Kegiatan BPD, Buku Angenda BPD, Buku Ekspedisi BPD. 
Adapun rangkaian kegiatan yang digolongkan sebagai administrasi mencakup :

1) Dilakukan oleh sekelompok orang (2 orang atau lebih)

2) Berlangsung dalam suatu kerja sama

3) Dimaksud untuk mecapai tujuan tertentu yang telah ditetapkan,

Ketiga faktor inilah yang merupakan tanda pengenal atau ciri khas daru administrasi yang apabila faktor-faktor tersebut disingkat adalh sekelompok orang-orang, kerjasama dan tujuan tertentu. Jadi biasa ditarik kesimpulan bahwa kerjasama adalah rangkaian perbuatan yang dilakukan bersama-sama secara teratur oleh lebih seorang yang meniumbulkan akibat yang sebenarnya tidak akan terjadi apabila dilakukan oleh masingmasing seorang diri.

Berdasarkan pengertian tersebut dan apabila dikaitkan dengan aktifitas ditingkat desa, maka berbicara tentang administrasi desa berarti yang dimaksud dengan "administrasi adalah rangkaian kegiatan yang dilakukan oleh penyelenggara pemerintah desa untuk mencapai tujuan pemerintah, seperti antara lain, baik dalam menggerakan partisipasi dalam pembangunan dan terwujudnya demokrasi pancasila secara nyata guna meningkatkan taraf hidup masyarakat.

\subsection{Tugas Dan Fungsi Pemerintah Desa}

Mengingat unit pemerintah desa adalah bagian integral dari pemerintahan nasional, maka pembahasan tentang tugas dan fungsi pemerintah desa tidak terlepas dari tugas dan fungsi pemerintahan nasional seperti yang telah diuraikan dalam Undang-undang Nomor 6 tahun 2014 tentang tugas pokok kepala Desa yaitu : a) Pelaksanaan kegiatan pemerintah desa, b) Pemberdayaan masyarakat, c) Pelayanan masyarakat, d) Penyelenggaraan ketentraman dan ketertiban umum, e) Pemeliharaan prasarana dan fasilitas pelayanan umum.

Oleh unit pemerintah desa seperti halnya pemerintah desa sebagai unit pemerintahan terendah mempunyai 3 fungsi pokok yaitu:

1. Pelayanan kepada masyarakat

2. Fungsi operasional atau manajemen pembangunan

3. Fungsi ketatausahaan atau registrasi

Keseluruhan tugas dan fungsi administrasi pemerintah desa tersebut, tidak akan trlaksana dengan baik, manakala tidak ditunjang dari aparatnya dengan melaksanakan sebaik-baiknya apa yang menjadi tangung jawab masing-masing aparat. Menyadari betapa pentingnya tugas administrasi pemerintahan desa, maka yang menjadi keharusan bagi Kepala Desa dan aparatnya adalah berusaha untuk mengembangkan kecakapan dan keterampilan mengelola organisasi pemerintahan desa termasuk kemampuannya untuk melaksanakan tugas-tugas dibidang pemerintahan, pembangunan dan kemasyarakatan.

Selanjutnya menurut Beratha mengemukakan bahwa tugas pemerintah desa termasuk dalam menjalankan administrasi adalah:

1. Tugas bidang pemerintah, meliputi: registrasi yang dilakukan dalam berbagai buku registrasi mngenai berbagai hal dan peristiwa yang menyangkut kehidupan tindakan masyarakat berdasarkan laporan yang 
diperoleh melalui sub pelayanan umum dari masyarakat yang bekepentingan. Tugas-tugas umum meliputi: menerima dan melaksanakan instruksi-instruksi dan petunjuk-petunjuk dari pemerintah kecamatan dan pemerintah kabupaten mengenai pemerintah, tugas-tugas teknis: ketertiban kesejahteraan dan keamanan, Membuat laporan periodik mengenai keadaan dan perubahan penduduk, keamanan serta sosial ekonomi. Melaksanakan hal-hal yang sudah menjadi keputusan ditingkat desa, melaksanakan kerja sama dengan instansi ditingkat desa dan menyelesaikan permasalahan yang berhubungan dengan tanah.

2. Tugas bidang pelayanan umum, meliputi, pemberian bermacam-macam izin, seperti izin tempat tinggal, izin meninggalkan desa, izin usaha dan izin pendirian bangunan.

3. Tugas bidang ketatausahaan, meliputi, pelaksanaan tugas dan fungsi desa tersebut, selanjutnya dijabarkan menjadi tugas dan fungsi masing-masing unsur aparat baik kepala desa maupun aparatnya yang terdiri dari: Sekretaris, Kepala-kepala Urusan, Kepala-kepala Lingkungan.

\section{METODE PENELITIAN}

\subsection{Jenis dan Sumber Data}

Penelitian ini menggunakan pendekatan penelitian kualitatif. Selanjutnya data yang ditelusuri meliputi data primer dan sekunder. Metode yang digunakan untuk menentukan sumber data dalam penelitian ini adalah Purposive Sampling yaitu teknik penentuan sumber data dengan pertimbangan tertentu, misalnya orang (nara sumber) tersebut dianggap paling tahu tentang apa yang kita harapkan (Sugiyono, 2005;96). Dengan metode Purposive Sampling maka sumber data dalam penelitian ini adalah Desa Karyamukti Kabupaten Gorontalo.

\subsection{Lokasi Penelitian}

Penelitian ini akan dilaksanakan di Desa Karyamukti Kecamatan Mootilango, Kabupaten Gorontalo Penentuan lokasi ini antara lain didasarkan atas pertimbangan bahwa di desa ini penyelengaraan administrasi pemerintahan seperti pencatatan register, belum terlaksana dengan baik sesuai format dan ketentuan yang telah ditetapkan. Terkait dengan pertimbangan tersebut juga karena Desa Karyaukti merupakan desa yang dekat dengan kecamatan dan seharusnya menyelenggarakan administrasi pemerintahannya dengan lebih baik, namun kenyataannya tidak demikian.

\subsection{Informan Penelitian}

Adapun yang menjadi informan dalam penelitian ini meliputi 1 (satu) orang Sekretaris Desa, 3 (tiga) orang Kepala Urusan maka kami menetapkan Kepala Desa Karyamukti sebagai informan kunci (key informan).

\subsection{Teknik Pengumpulan dan Pengolahan Data}

Untuk mendapatkan data dalam penelitian ini, baik data primer maupun data sekunder, dipergunakan beberapa teknik yaitu wawancara, observasi, dan dokumentasi. Wawancara dilakukan dengan tanya jawab langsung dengan para informan, dengan menggunakan pedoman wawancara. Sumber-sumber data yang akan diwawancarai dalam penelitian ini adalah: Kepala Desa Karyamukti sebagai informan kunci (key informan), Sekretaris Desa, Tiga orang Kepala Urusan. Observasi, yaitu secara langsung mengamati obyek yang menjadi kajian, terutama mengamati secara langsung masing-masing aparat dalam 
pelaksanaan tugas sehari-hari disamping mengamati cara kerja dan hasil kerja mereka. Kaji Dokumen, yaitu menelaah dokumen-dokumen laporan hasil pelaksanaan tanggung Jawab masing-masing aparat.

\subsection{Analisis Data}

Analisis data penelitian merupakan langkah yang sangat kritis dalam melakukan penelitian yang bersifat ilmiah, karena dari analisis data itulah akan didapatkan arti dan makna dalam memecahkan masalah-masalah yang akan diteliti. Data yang terkumpul selama peneliti melakukan penelitian, akan diklasifikasi, dianalisis dan diinterpretasikan secara mendetail, teliti dan cermat untuk memperoleh kesimpulan yang lebih obyektif dari suatu penelitian. Analisis data dalam penelitian ini akan dilakukan secara mendalam sebagai upaya mencari dan menata secara sistematis catatan hasil observasi, wawancara dan informasi lainnya untuk meningkatkan pemahaman peneliti tentang kasus yang diteliti.

\section{HASIL DAN PEMBAHASAN}

\subsection{Kemampuan Aparat Desa dalam Pelaksanaan Tugas Administrasi Pemerintah di Desa Karyamukti}

Seperti yang telah diuraikan sebelumnya, bahwa tugas dan fungsi pemerintah dalam demikian luas dan kompleks yaitu meliputi seluruh aspek kehidupan masyarakat. Desa merupakan kesatuan masyarakat hukum yang memiliki kewenangan untuk mengatur dan mengurus kepentingan masyarakat setempat berdasarkan asal usul dan adat istiadat setempat. Kajian politik pada pasal 18 UUD 1945 mencerminkan pengakuan negara terhadap otonomi desa. Desa sebagai susunan asli memiliki hak asal usul dan hak otonom. Adapun daerah-daerah besar dan kecil lainya, semacam provinsi, kabupaten ataupun kota yang dikenal dalam sistem pemerintahan bersifat otonom karena pemberian pusat terhadap hak otonom bagi daerah-daerah tersebut. Otonomi daerah ini sebagai konsekuensi desentralisasi di Indonesia.

Proses pemerintah desa Karyamukti merupakan suatu peran yang dilakukan oleh aparat desa dalam melaksanakan administrasi pemerintahan desa. Salah satu tugas aparat desa adalah sebgai kepala urusan pemerintahan memiliki tugas yaitu Membantu Kepala desa untuk melakukan pengelolaan administrasi kependudukan, administrasi pertanahan, pembinaan, ketertiban masyarakat suatu desa, persiapan bahan dalam pelaksanaan kebijakan seperti kebijakan penataan dan kebijakan hukum desa. Sementara itu, fungsi pokok kepala urusan umum yaitu melaksanakan administrasi kependudukan, mempersiapkan bahan untuk menyusun rancangan peraturan serta keputusan kepala desa, melaksanakan administrasi pertanahan, mencatatat monografi desa, mempersiapkan bantuan yang bertujuan untuk memperlancar penyelenggaraan dalam pemeritahan di desa dan melakukan penataan kelembagaan masyarakat, dan melakukan tugas lain yang diberikan atau diperintahkan oleh kepaladesa.

Menurut kepala desa Karamukti Abdul Wahab Pomala menyatakan bahwa peran kepala urusan pemerintahan dalam administrasi pemerintahan belum berjalan secara optimal. Karena peranan itu belum bisa secara mandiri dilaksanakan, apakah itu terkait dengan administrasi kependudukan, administrasi pertanahan, dan lain-lain. Semua tugas tersebut selalu dikomunikasikan kepada saya selaku kepala desa sehingga semua urusan 
kepala urusan pemerintahan menjadi tanggung jawab saya. Padahal begitu banyak urusan yang harusnya diselesaikan namun karena keterbatasan kaur pemerintahan terpaksa harus dibantu terlebih dahulu. (Hasil Wawancara, 25 Agustus 2017).

Berdasarkan hasil wawancara tersebut menunjukkan bahwa kepala urusan pemerintahan di desa Karyamukti masih memiliki peran yang kurang maksimala dalam urusan administrasi pemerintahan desa. Kelemahan itu terlihat mulai dari tugas kaur pemerintahan dalam Membantu Kepala desa untuk melakukan pengelolaan administrasi kependudukan, administrasi pertanahan, pembinaan, ketertiban masyarakat suatu desa, maupun persiapan bahan dalam pelaksanaan kebijakan seperti kebijakan penataan dan kebijakan hukum desa. Hal tersebut juga diakui oleh Saira Kasim, kepala urursan pemerintahan desa Karamukti juga menyatakan bahwa masih banyak yang tidak dimengerti dalam administrasi pemerintahan, karena itu administrasi belum berjalan secara optimal.

Sementara itu, Tugas aparat desa sebagai Kepala Urusan Pembangunan yaitu membantu kepala desa dalam mempersiapkan bahan untuk perumusan kebijakan teknis dalam hal pengembangunan potensi desa, mengelola administrasi pembangunan, mengelola pelayanan masyarakat. Fungsi kepala urusan pembangunan yaitu sebagai pelaksana dalam kegiatan administrasi pembangunan; mempersipakan bantuan untuk kajian perkembangan ekonomi warga masyarakat; dan Melakukan tugas lain yang diberika atau diperintahkan oleh kepala desa.

Menurut kepala desa Karyamukti peran aparat yang bertugas sebagai kepala urusan pembangunan juga selalu berusaha secara maksimal dapat bekerja dengan baik. Namun dalam menjalan tugas dan fungsinya masih juga belum maksimal karena belum bisa membantu kepala desa dalam mempersiapkan perumusan kebijakan teknis, seperti penbangan potensi desa, mengelola administrasi pembangunan, dan juga memberikan pelayanan prima kepada masarakat.

Hal tersebut menunjukkan bahwa kepala urusan pemerintahan belum bisa secara optimal melaksanakan tugasnya dengan baik. Hal itu akibat karena sumber daya yang dimilikinya masih sangat terbatas dan masih berada dalam proses pembelajaran. Oleh karena itu kepala urusan pembangunan belum dapat membantu kepala desa dalam mempersiapkan perumusan kebijakan teknis, seperti penbangan potensi desa, mengelola administrasi pembangunan, dan juga memberikan pelayanan prima kepada masarakat.

Berdasarkan hasil wawancara dengan Kepala urusan pembangunan Maram Lihawa menyatakan bahwa kapasitas aparat desa di desa Karyamukti masih terbatas. Terbukti dengan adanya kepala urusan pembangunan yang belum bergerak mandiri dalam proses yang berkaitan langsung dengan tugas dan fungsinya. Oleh karena itu perlu ada penataan dalam bentuk program pendidikan dan pelatihan kepada aparat desa, sehingga dapat mengatasi kekurangan yang ada pada aparat desa. Kemampuan aparat desa sangat penting dalam mendorong pelaksanaan administrasi pemerintahan desa di desa Karya Mukti. Di samping itu masih minimnya kemampuan aparat dalam mempersipakan perumusan kebijakan terutama untuk perumusan kebijakan teknis dalam hal pengembangunan potensi desa, mengelola administrasi pembangunan, dan mengelola pelayanan masyarakat belum dapat maksimal 
apabila dikerjakan sendiri. Hal tersebut menunjukkan bahwa kemampuan aparat desa masih terbatas dalam melaksanakan tugas dan fungsinya.

Selain kepala urusan pembangunan juga masih terdapat Tugas aparat desa sebagai Kepala Urusan Umum yaitu membantu sekretaris desa dalam melaksanakan tugas administrasi umum, kearsipan, tata usaha, inventaris desa, dan menyiapkan segala bahan untuk rapat dan pembuatan laporan. Adapun fungsi kepala urusan umu yaitu Pengendalian kearsipan dan surat masuk serta surat keluar, mencatat inventaris atau kekayaan desa, Melakukan tugas administrasi umum, Menyimpan, menyediakan, dan menyalurkan alatalat tulis kantor serta bertanggungjawab dalam memelihara dan perbaikan terhadap perabot atau perlengkapan kantor, melaksanakan pengelolaan administrasi perangkat desa, menyiapkan bahan untuk membuat laporan, dan melakukan tugas lain yang diperintahkan oleh sekretaris desa.

Kepala desa Karyamukti menyatakan bahwa kinerja aparat desa masih bisa dikatakan masih bersifat standar atau dalam bahasa saya sebenarnya masih lemah. Karean Kepala Urusan Umum dalam membantu sekretaris desa dalam melaksanakan tugas administrasi umum, kearsipan, tata usaha, inventaris desa, dan menyiapkan segala bahan untuk rapat dan pembuatan laporan masih memiliki peran yang kecil. Karena semua urusan administrative dikerjakan oleh sekertaris desa Karyamukti. Makanya saya mengatakan bahwa aparat desa ya hanya bekerja seperti itu saja.

Hal tersebut menunjukkan bahwa peran aparat desa di desa Kayumukti masih kurang maksimal. Karena kepala urusan umum kurang mampu dalam melaksanakan tugas dan perannya melainkan lebih dimonopoli oleh sekretaris desa Kayumukti. Dengan keadaan di desa tersebut diharapkan agar peran masing-masing bagian dalam organisasi pemerintahan desa dapat berjalan maksimal agar kinerja aparat dalam pembangunan desa berjalan efektif. Hal ini sejalan dengan hasil wawancara dengan Sasmita Taliki, Kepala Urusan Umum di desa Karyamukti menyatakan bahwa aparat belum memiliki kemampuan yang maksimal.

Pencatatan atau register adalah suatu aktivitas pemerintahan dengan maksud untuk mendokumentasikan berbagai peristiwa dan atau kegiatan yang telah terjadi melalui pencatatan-pencatatan di dalam format yang telah ditetapkan. Daftar register dalam penyelenggaraan pemerintahan pada tingkat dalam hingga sekarang ini yang digunakan di Desa Karyamukti adalah berdasarkan pada Kepmendagri Nomor 414.3/316/PMD/2003, tentang Register Dalam. Dalam Keputusan tersebut, ditetapkan adanya tiga jenis buku yang terdiri dari Buku Administrasi Umum, meliputi Buku Kekayaan dan inventaris dalam, buku tanah, buku keputusan dalam dan buku agenda; Buku Administrasi Penduduk, meliputi Buku Induk Penduduk dan Buku Rekapitulasi Penduduk Akhir Bulan, dan Buku Administrasi Keuangan meliputi Buku Kas Umum dan Buku Kas Pembantu.

Berdasarkan hasil penelitian menunjukkan bahwa pelaksanaan tugas pemerintahan Desa karyamukti dalam pencatatan atau pengisian Buku-buku register tersebut, dapat dinilai tidak efektif. Hal tersebut terlihat dari sembilan buku register yang harus diisi oleh perangkat desa, ternyata yang terisi hanya 5 buku, yaitu : Buku Agenda, Buku Aparat, Buku Keputusan Dalam, Buku Induk Penduduk dan Buku Kas Pembantu. 
Lebih lanjut dapat dijelaskan bahwa buku yang terisi tersebut, data atau informasinya tidak akurat dan tidak lengkap. Rincian tentang ketidaklengkapan pengisian buku-buku tersebut, diantaranya pertama, buku agenda adalah buku tentang pencatatan surat-surat masuk dan keluar. Dalam penelitian ini tercatat 14 surat masuk dan 8 surat keluar. Dan penelitian yang dilakukan pada buku agenda terlihat bahwa 10 kolom yang tersedia pada agenda surat masuk ternyata kolom 5, 6, 7, 10 yaitu : nama instansi yang mengirim, penanggung jawab pengelola dan kolom keterangan tidak terisi. Kedua, buku aparat adalah buku tempat pencatatan berbagai informasi tentang keadaan aparat pemerintah dalam. Dari 11 kolom yang tersedia, ternyata yang terisi hanya 6 kolom, sedangkan yang tidak terisi sebanyak 5 kolom, yaitu ; kolom NIP, Tempat dan tanggal lahir, Pangkat/Golongan, Tanggal Keputusan Pengangkatan dan kolom keterangan.

Aspek Ketiga, buku keputusan dalam adalah buku tempat mencatat data/informasi mengenai, kebijakan atau keputusan pemerintah dalam, sehubungan dengan penyelenggaraan pemerintahan dan pembangunan di tingkat dalam. Keempat, Buku Induk Penduduk adalah buku tempat mencatat seluruh penduduk yang menjadi warga di dalam tersebut, serta berbagai karakteristik yang melingkupi, setiap individu warga tersebut. Kelima, Buku Kas Umum adalah buku tempat pencatatan setiap kegiatan penerimaan rutin dan pembangunan serta pengeluaran dan pembangunan setiap hari. Buku Kas umum berfungsi untuk mengetahui berapa jumlah penerimaan dan pengeluaran setiap hari terhadap keadaan uang tunai yang ada pada kas dalam.

Pembuatan dan pencatatan Monografi merupakan salah satu tugas dari perangkat desa. Tugas tersebut perlu dilaksanakan dan untuk selanjutnya ditampilkan dalam ruang kantor. Hal ini penting mengingat papan monografi tersebut dapat memberikan informasi dan data kepada pihak luar atau masyarakat umum tentang keadaan Wilayah dengan berbagai potensinya. Namun pada kunjungan kekantor desa tidak ada peneliti temukan. Penyimpanan dokumen-dokumen atau arsip secara baik adalah salah satu tugas perangkat desa. Dengan penyimpanan arsip yang baik dapat membantu aparat desa upaya menemukan kembali, jika data itu dibutuhkan untuk suatu kepentingan. Namun dari kaji dokumen dan pengamatan penulis, ternyata tugas tersebut tidak dilaksanakan dengan baik. Hal ini terbukti dengan tidak ditemukannya arsip dan atau register-register yang tidak dipaparkan sebelumnya pada kantor. Akan tetapi daftar register dimaksud tersimpan dan atau berserakan di rumah Kepala desa.

Berdasarkan seluruh uraian sebelumnya, khususnya uraian tentang kondisi rill pelaksanaan, tugas perangkat desa dalam arti sempit, yang meliputi : pencatatan register, pembuatan dan pencatatan monografi dalam, dan penyimpanan dokumen/arsip, diperoleh gambaran bahwa pelaksanaan tugas aparat desa dapat dinilai kurang efektif. Hal tersebut terlihat dari tidak akuratnya data dan atau informasi yang diuraikan dan tidak terealisasinya seluruh tugas dan fungsi yang menjadi tugas dan fungsi masing-masing aparat desa. Bahkan data-data atau informasi yang dipaparkan tidak "op to date" lagi, karena data/informasi yang berlangsung adalah data/informasi yang belangsung beberapa tahun sebelumnya yaitu data antara tahun 2008 hingga tahun 2012. 
Tidak efektifnya pelaksanaan tugas perangkat desa dapat diketahui melalui aktifitas kearsipan atau penyimpanan dokumen yang tidak efektif, bahkan cenderung gagal dilaksanakan sebagaimana mestinya. Maksudnya adalah bahwa arsip-arsip surat-menyurat yang harusnya disusun dan tersimpan pada kantor tetapi hal itu tidak dilakukan. Akan tetapi dokumen/arsip Surat-Surat dimaksud tidak disimpan rapi (berserakan), sehingga sangat sulit untuk menemukannya kembali bila dibutuhkan. Selain itu, dari pengamatan peneliti selama melakukan penelitian terlihat bahwa aparat atau perangkat desa kurang efektif dalam melaksanakan tugas sehari-hari, bahkan cenderung tidak efektif ditinjau dari aspek disiplin waktu. Hal ini terlihat dari kehadiran aparat pada setiap hari kerja sangat terbatas, bahkan sering terjadi seorang aparat tidak masuk kantor selama satu minggu. Bahkan kadangkala pada hari-hari tertentu kantor tidak terbuka karena aparat tidak ada yang hadir. Akibatnya sering terjadi pelayanan pada masyarakat dilakukan di rumah aparat, terutama di rumah Kepala Desa atau Sekretaris Desa. Keadaan tersebut, semakin memperjelas, bahwa pelaksanaan tugas perangkat desa dalam urusan administrasi pemerintahan desa masih tidak efektif.

Dari beberapa uraian tersebut diatas, maka dapat ditarik suatu kesimpulan bahwa Peranan Aparat Desa dalam pelaksanaan tugas administrasi pemerintahan di Desa Karyamukti Kecamatan Mootilango kabupaten Gorontalo masih kurang maksimal. Penilaian tersebut karena dari tiga kepala urusan, baik pemerintahan, pembangunan, dan umum mengakui bahwa perannya belum maksimal dalam melakasanakan tugas dan fungsinya secara efektif.

\subsection{Faktor - Faktor yang Mempengaruhi Kemampuan Aparat dalam Pelaksanaan Tugas Administrasi Pemerintahan Desa Karyamukti}

\subsubsection{Disiplin Aparat Desa}

Upaya pemberdayaan dapat dilakukan untuk meningkatkan efisiensi dan efektifitas kerja aparatur desa Karyamukti dalam melaksanakan tugas pokoknya dan fungsi organisasi adalah melalui pembinaan disiplin, hal ini dimaksudkan agar para pegawai dalam melaksanakan tugas sehari-harinya senantiasa patuh dan taat pada berbagai ketentuan yang berlaku dan menunjukan prestasi kerja yang tinggi. Usaha untuk meningkatkan kualitas kerja melalui pembinaan disiplin, diperlukan suatu pedoman atau kerangka yang memuat dengan jelas sistem metode dan prosedur pembinaan serta tujuan dan sasaran setiap bentuk pegawai yang bermental baik berdaya guna, berhasil guna dan sadar akan tanggung jawab dalam melaksanakan dan menjalankan tugas-tugas pemerintahan dan pembangunan.

Adapun bentuk penerapan disiplin pegawai pada Kantor Desaa Karyamukti dalah pembinaan disiplin waktu kerja, sebab dengan ketepatan pada jam masuk kantor sangat erat kaitannya dengan disiplin lainnya. Menurut pengamatan penulis bahwa penerapan disiplin waktu jam kerja pada dasarnya belum dilaksanakan dengan baik. Pelanggaran disiplin waktu bagi aparat desa Karyamukti cenderung sering terjadi.

Faktor disiplin yang dimaksud dalam uraian ini adalah disiplin ditinjau dari aspek ketepatan dan kebutuhan setiap aparat terhadap waktu yang telah ditentukan pada setiap hari kerja. Dari uraian sebelumnya menunjukkan bahwa umumnya aparat pemerintan Desa Karyamukti kurang efektif dalam melaksanakan tugas dan tanggung jawabnya atau dengan kata lain, bahwa 
salah satu faktor yang berpengaruh negatif dan dapat menghambat kemampuan terhadap pelaksanaan tugas-tugas administrasi dalam adalah ketidakdisiplinnya aparat desa pelaksanaan tugas mereka. Karena dengan disiplin maka kesadaran aparat desa dapat mempengaruhi kesadaran masayara di desa Karyamukti untuk ikut serta berpartisifasi dalam pemerintahan dan pembangunan desa.

Kesadaran masyarakat menjadi suatu factor yang menghambat jalanya pelayanan masyarakat. Dimana kesadaran masyarakat memaksudkan ialah dengan kesadaran untuk mempersiapkan segala yang menjadi persyaratan untuk melakukan suatu urusan pelayanan di kantor desa.

Berdasarkan hasil wawancara dengan kepala desa Karya Mukti menyatakan bahwa, masalah disiplin aparat desa memang masih kurang, karena mayoritas masalah administrasi itu dilaksanakan langsung oleh sekertarid desa. Selain itu urusan-urusan penting pemerintahan desa mulai yang terkecil sampai yang terbesar menjadi tugas pokok saya, apakah itu diatur atau tidak, pokoknya semua adalah tugas saya selaku pemerintah desa di desa Karyamukti ini. Oleh karena itu kalo mau kinerja aparat baik maka harus disiplin, tetapi umumnya desa terkendala pada persoalan kesejahteraan.

Disiplin kerja merupakan faktor penting yang bisa menambah kemampuan aparat desa dalam proses administrasi pemerintahan desa. Namun yang terjadi didesa Karyamukti masih kurang disiplin karena beberapa aparat jarang masuk kantor karena adanya kesibukan diluar. Hal itu akibat karena kesejahteraan yang tersedia dikantor desa belum tersedia dalam memenuhi kebutuhan aparat desa, sehingga membuat mencari tambahan pendapatan dari luar kantor desa. Hal ini yang menyulitkan aparat desa bisa focus dan masuk kantor setiap harinya. Oleh karena itu, masalah kesejahteraan merupakan satu aspek yang perlu dipikirkan bersama-sama dalam membangun kesejahteraan aparat desa dalam melaksanakan tugas dan fungsinya dengan baik.

Pendapatan aparat berfungsi sebagai pendukung pelaksanaan pelayanan kepada masyarakat. Pendapatan yang cukup akan memotivasi pegawai dalam melaksanakan pekerjaan yang baik. Selama ini masyarakat yang tempat tinggalnya jauh dari kantor desa lebih banyak menggunakan cara yang kolektif, sehingga hal tersebut memacu keinginan dari khusunya aparat desa untuk membenahi pemohon dengan biaya lebih tinggi.

Menurut Kepala urusan pemerintahan desa Karyamukti menyatakan bahwa masalah kesejahteraan merupakan salah satu faktor aparat di desa karyamukti kurang dapat disiplin dalam bekerja karena memiliki kebutuhan diluar kantor yang cukup penting demi memenuhi kebutuhan keluarga. Hal ini menunjukkkan bahwa begitu pentingnya masalah kesejahteraan aparat, sehinggga mereka dapat bekerja dengan disiplin dan memiliki tanggung jawab penuh dalam mengembang tugas dan fungsi. Karena bagaimanapun organisasi pemerintahan desa diharapkan dapat berjalan secara efektif, dan seluruh struktur didalam dapat berjalan dengan baik. Namun kenyataan menunjukkan bahwa masih sulit dalam mewujudkan disiplin kerja bagi aparat karena masalah kesejahteraan yang masih dinilai rendah. Oleh karena itu, masalah pokok yang harus diselesaikan adalah peningkatan kesejahteraan terhadap aparat, sehinggan perannya dalam administrasi pemerintahan desa di desa Karyamukti dapat berjalan efektif sesuai dengan tugas dan fungsi masing-masing aparat desa. 


\subsubsection{Pendidikan dan Pelatihan}

Pendidikan dan pelatihan adalah merupakan upaya untuk memberdayakan aparat, terutama untuk meningkatkan kemampuan intelektual dengan kepribadian manusia. Pendidikan yang dilakukan dalam suatu proses pengembangan kemampuan bertujuan kearah yang diinginkan oleh organisasi yang bersangkutan. Sedangkan pelatihan adalah merupakan bagian dari proses pendidikan yang bertujuan untuk meningkatkan kemampuan atau keterampilan khusus seseorang.

Pendidikan dan pelatihan yang diikuti oleh aparat Desa Karyamukti diharapkan nantinya mampu mengerjakan tugas-tugasnya dengan baik yang dibebankan kepadanya tanpa arahan langsung dari pihak atasannya. Pendidikan dan pelatihan dapat dipandang sebagai salah satu jalur untuk meningkatkan kemampuan aparat desa usaha melayani kepentingan masyarakat. Pentingnva program pendidikan dan pelatihan adalah bertujuan: Untuk meningkatkan kemampuan mereka dalam mengelolah kegiatan-kegiatan sesuai dengan profesinya.

Adapun tingkat pendidikan yang dimilikioleh aparat desa di desa karyamukti adalah 3 orang berpendidikan SMA yang kesemuanya merupakan kepala urusan, baik pemerintahan, pembangunan, maupun umum. Hal ini menunjukkan bahwa tingkat pendidikan aparat desa masih perlu dtingkatkan gunan meningkatkan peran aparat desa dalam urusan adminstrasi pemerintahan desa di desa Karyamuti Kabupaten Gorontalo. Menurut Kepala Desa Karyamukti menyatakan bahwa, perlu adanya pelatihan dan pendidikan kepada aparat desa di desa Karyamukti gunan meningkatkan kemampuan aparat. Secara strategis dibutuhkan kemampuan teknis seperti computer, dan urusan administrasi pemerintahan desa lainnya. Karena kalau tidak maka aparat desa kami akan begin terus. Pemerinrah daerah dalam melakukan pendidikan dan pelatihan menurut kami tidak maksimal karena sifatnya sesaat dan belum menyentuh masalah mendasar didesa kami. Apalagi dengan anggaran yang besar maka tuntutannya adalah aparat desa harus mampu mengendalikan semua dengan baik.

Masalah utama yang dihadapi guna meningkatkan kemampuan aparat desa di desa Karyamukti adalah adalah peningkatan kapasitas aparat desa yang masih terbatas. Pendidikan dan pelatihan adalah salah satu unsur pokok yang akan membantu aparat dalam meningkatkan kemampuannya dalam urusan administrasi pemerintahan desa. Karena tanpa adanya peningkatan kemampuan aparat desa dalam menjalan tugas dan fungsinya, maka sulit untuk bisa memiliki kinerja yang maksimal sebagaimana yang diharapkan oleh kepala desa. Bentuk lain yang juga perlu dilakukan kepala desa adalah motivasi kerja diberikan kepada aparat desa.

Bentuk motivasi kerja yang di berikan oleh kepala desa adalah memberikan dorongan dan menyerahkan sepenuhnya tugas-tugas kepada bawahannya untuk dilaksanakan dengan penuh rasa tanggung jawab. Untuk meningkatkan kualitas sumberdaya aparat Desa Kayumukti, maka semua aparat yang telah mengikuti program pendidikan dan pelatihan diberikan kesempatan untuk mengembangkan karirnya di tempat kerjanya yang sebagai salah satu upaya pemberdayaan aparat. Pengembangan karir berarti bahwa seorang pegawai ingin terus berkarya dalam organisasi tampatnya bekerja untuk jangka waktu yang 
lama. Demikian Hal tugas lainnya seperiti kepala urusan pemerintahan, kepala urusan pembangunan, kepala urusan umum, dan lain sebagainya.

Aparat desa di desa Karyamukti memang masih memmbutuhkan pendidikan dan pelatihan untuk mendorong adanya peningkatakan kemampuan aparat dalam urusan adminstrasi pemerintahan desa. Karena aparat menyadari bahwa selama ini memang masih dinilai kemampuan yang dimiliki masih rendah. Peningkatan kemampuan tersebut akan mendorong pengembangan karier aparat pemerintah desa di desa Karyamukti. Tujuan pengembangan karir tersebut diatas diharapkan pada bawahan nantinya mampu untuk menyelesaikan masalah-masalah yang dihadapi dalam organisasi dengan berdasarkan pada pendidikan dan pelatihan yang mereka dapatkan dalam pengembangan karirnya. Untuk memberikan pelayanan yang maksimal kepada masyarakat sangat dibutuhkan aparatur-aparatur pemerintah desa yang memiliki kualitas sumber daya manusia yang handal, untuk itulah kemudian dapat dikatakan keberhasilan suatu pelayanan salah satunya sangat ditentukan oleh kualitas aparat pemerintah yang ditunjuk sebagai pelayanan kepada masyarakat.

Menurut Moenir (1992) dalam pelayanan terdapat faktor pendukung yang dinilai penting, yaitu kesadaran para aparat yang berkecimpung dalam kegiatan pelayanan publik. Kesadaran Aparat Desa pada segala tingkatan terhadap tugas yang menjadi tanggungjawabnya membawa dampak positif terhadap organisasi Desa. Dengan kesadaran penuh dari semua pihak maka itu akan mempengaruhi proses kinerja aparat pemerintah desa di desa Karyamukti untuk dapat bekerja dengan optimal.

\subsubsection{Faktor Sarana dan Prasarana}

Sarana dan prasaran merupakan faktor utama yang sangat menunjang proses kinerja aparat desa di desa Karyamukti. Ketersediaan sarana dan prasarana diperlukan dalam proses urusan administrasi pemerintahan desa. Tanpa sarana dan prasarna yang memadai maka akan berpengaruh pada proses administrasi pemerintahan desa di desa Karyamukti.

Sarana dan prasarana merupakan alat penunjang keberhasilan suatu proses upaya yang dilakukan dalam pelayanan kepada masyarakat. Dimana sarana ini seperti peralatan, perlengkapan serta pasilitas lain seperti pasilitas komunikasi dan fasilitas kemudahan lainya. Menurut kepala desa Karyamukti Abdul Wahab menyatakan bahwa, anggaran desa yang dikelola saat ini memang nilai jauh lebih besar ketika Jokowi jadi presiden, namun itu diperuntukkan untuk pembangunan fisik. Sementara dana dari APBD masih terbatas sehingga masih membatasi dalam hal sarana dan prasarana. Karena itu untuk memenuhi sarana dan prasarana dengan baik maka kami kepala desa berharap agar pemerintah daerah Kabupaten Gorontalo dapat memenuhi amanah UU Nomor 6 tahun 2014 tentang desa yang didalamnya mengatur tentang alokasi APBD terdapat $10 \%$ untuk pemerintah desa.

Meskipun anggaran besar masuk ke desa saat ini, tetapi belum leluasa diatur oleh pemerintah terutama untuk mendorong kemampuan pemerintah desa dan juga melengkapi sarana dan prasarana pemerintah desa saat ini. Hal ini akibat amanah UU Nomor 6 tahun 2014 tentang desa belum sepenuhnya dapat dilaksanakan amanahnya oleh pemerintah daerah Kabupaten Gorontalo tentang alokasi APBD sebanyak $10 \%$ dari total anggaran. 
Adapun daftar sarana dan prasaran kantor desa Karyamukti sebagai berikut:

Tabel. Daftar Infentaris Desa Karyamukti

\begin{tabular}{ll}
\hline \multicolumn{1}{c}{ Inventaris } & \multicolumn{1}{c}{ Jumlah } \\
\hline Kendaraan Roda dua & 3 \\
\hline Laptop & 5 \\
\hline Meja & 8 \\
\hline Lemari & 6 \\
\hline Kursi & 75 \\
\hline Printer & 3 \\
\hline \multicolumn{2}{c}{ Sumber: Data Kantor Desa Karyamukti 2017 }
\end{tabular}

Tabel tersebut diatas menunjukkan bahwa inventaris desa Karya mukti terdapat 3 kendaraan roda dua, lemari sebanyak 6, kursi sebanyak 75, laptop sebanyak 5, dan printer sebanyak 3 . Diantara 3 kendaraan roda, terdapat dua dinyatakan rusak dan hanya ada satu kendaraan yang beroperasi. Begitupun dengan printer, dari 3 unit printer yang masih berada dalam keadaan baik adalah 2 unit dan 1 unit rusak. Dengan melihat daftar inventaris barang maka peneliti menilai bahwa sarana dan prasarana didesa Karyamukti masih kurang. Oleh karena itu diharapkan dapat dimaksimalkan sehingga sarana dan prasarana pemerintah desa Karyamukti dapat menunjang aparat desa dalam melaksanakan tugas administrasi pemerintahan desa seacar efektif.

Selain sarana dan prasarana, masalah yang dihadapi oleh aparat juga adalah masalah gaji aparat desa di desa Karyamukti masih dinilai kurang, sehingga berpengaruh pada konsentrasi dalam menjalankan tugas pada masingmasing aparat desa. Oleh karena itu, maka diharapkan supaya pemerintah dapat meningkatkan gaji atau kesejateraan aparat desa sehingga bisa bekerja dengan foKus dalam melaksanakan tugas dan fungsinya.

\section{PENUTUP}

Berdasarkan hasil penelitian dan pembahasan penelitian tentang Peran Aparat Desa Dalam Melaksanakan Tugas Administrasi Pemerintahan Di Desa Karyamukti Kab. Gorontalo, maka peneliti memberikan kesimpulan bahwa : pertama, peranan Aparat Desa dalam pelaksanaan tugas administrasi pemerintahan di Desa Karyamukti Kecanatan Mootilango kabupaten Gorontalo masih kurang maksimal. Penilaian tersebut karena dari tiga kepala urusan, baik pemerintahan, pembangunan, dan umum mengakui bahwa perannya belum maksimal dalam melakasanakan tugas dan fungsinya secara efektif. Kedua, Faktor-faktor yang mempengaruhi upaya peningkatan kempuan aparat desa dalam pelaksanaan tugas administrasi pemerintahan di desa karyamukti yaitu Disiplin kerja, pendidikan dan latihan, sarana dan prasarana serta tingkat kesejahteraan aparat pemerintah desa. Dalam penelitian ini disarankan agar pemerintah daerah membuat suatu program pendidikan dan pelatihan guna meningkatkan kapasitas aparat pemerintah desa, baik kaur pemerintahan, kaur pembangunan, dan kaur umum dan Pemerintah daerah perlu mengatur peningkatan kesejahteraan aparat desa dengan baik sehingga ada keseimbangan antara beban kerja dengan tugas dan fungsi yang dilaksanakan aparat desa di Kabupaten Gorontalo. 


\section{DAFTAR PUSTAKA}

Amirin, Tatang M. 1990. Menyusun Rencana Penelitian, Rajawali Press J

Beratha, I Nyoman. 1992. Desa, Masyarakat Desa dan Pembangunan. Ghalia Indonesia.

Kartono, Kartini. 1993. Pemerintahan dan Kepemimpinan. Rajawali Press.

Rasyid, M. 1992. Pembangunan Kualitas dan Usaha-Usaha Peningkatan Aparatur Pemerintah. Universitas Tadulako Palu

Sawe, Jamaluddin. 1996. Konsep Dasar Pembangunan Pedesaan. APDN Press.

Saparin, Sumber. 1996. Tata Pemerintahan dan Administrasi Pemerintahan Desa. Ghalia Indonesia.

Siagian, SP. 1991. Administrasi Pembangunan. Haji Masagung. Jakarta

Singarimbun, Masri dan Sofyan Efendi. 1984. Metode Penelitian Survey. LP3ES.

Syarif, Roesli. 1991. Teknik Manajemen Latihan dan Pembinaan. Bina Aksara. Bandung

Tjiptoherianto, Prijono. 1993. Pembangunan Sumber Daya Manusia. Prisma.

Widjaya, AW. 1992. Pemerintahan Desa dan Administrasi Desa. Rajawali Press. 